\title{
Trafficking of women and girls in the District of Seke: Lessons from the Zimbabwe's Second Republic
}

\section{Perdagangan perempuan dan anak perempuan: Pelajaran dari Republik Kedua Zimbabwe}

\author{
Maybe Zengenene ${ }^{1,2}$ \\ ${ }^{1}$ Department of Sociology, Universitas Airlangga, Surabaya, Indonesia \\ ${ }^{2}$ Department of Religious Studies, Classics and Philosophy, University of Zimbabwe \\ Address: ${ }^{1}$ Dharmawangsa Dalam, Airlangga, Surabaya, East Java, Indonesia 60286 \\ ${ }^{2} 630$ Churchill Avenue, Harare, Zimbabwe \\ E-mail: maybe.zengenene-2018@fisip.unair.ac.id
}

Article History: Received 30 December 2019; Accepted 11 August 2020; Published Online 31 August 2020

\begin{abstract}
The study explores the phenomenon of human trafficking in Zimbabwe's second republic under President Emerson Mnangagwa. Using conflict theory, the study argues that the discourse of human trafficking in Zimbabwe is a complex phenomenon that has led to women's and girls' vulnerability in the Seke District. Primary data gathered from five female core informants who have been the direct victims of human trafficking and three significant others who were the parents and guardians of human trafficking victims. The snowball sampling technique was employed to obtain the female core informants for the in-depth interviews. The study also benefitted from secondary sources such as journal articles, online newspapers, government, and international UN, ILO, UNESCO, and UNICEF reports. The results of this study show that eco-socio and political ills such as a high rate of unemployment, a shortage of essential goods, cash, corruption, electricity, gender inequality, poverty, power relations and the continuous harassment by the security forces such as the police and the army have escalated the vulnerability of women to human trafficking in Zimbabwe. Since Zimbabwe's eco-political situation is a powerful determinant of both the continuation and abandonment of the human trafficking social phenomena, this study recommends that the present government solve the grassroots causes of the phenomena. With enforcement at the grassroots level and regional and international initiatives, human trafficking can be combated.
\end{abstract}

Keywords: human trafficking; women; Zimbabwe Second Republic; eco-socio; conflict theory

\begin{abstract}
Abstrak
Penelitian ini mengeksplorasi fenomena perdagangan manusia di Republik Kedua Zimbabwe dibawah pemerintahan presiden Emerson Mnangagwa. Menggunakan teori konflik, studi ini berargumen bahwa perdagangan manusia di Zimbabwe adalah fenomena kompleks yang berimplikasi pada peningkatan kerentanan pada para perempuan dan gadis atas tindakan perdagangan manusia di Distrik Seke. Data primer didapatkan dari lima informan perempuan yang telah menjadi korban dari perdagangan manusia dan tiga informan sebagai orang tua dan wali dari para korban. Penelitian ini menggunakan teknik snowball sampling untuk mendapatkan informasi melalui wawancara mendalam. Penelitian ini juga didukung data sekunder dari artikel jurnal, media daring, serta laporan organisasi internasional seperti PBB, ILO, UNESCO, UNICEF. Penelitian ini menemukan bahwa masalah eko-sosial serta politik meliputi tingginya angka pengangguran, kekurangan pemenuhan kebutuhan dasar yakni uang, barang, dan listrik, tingginya angka korupsi, ketimpangan gender, kemiskinan, relasi kuasa, dan gangguan dari aparat seperti polisi dan militer menjadi faktor yang memperparah kerentanan wanita atas perdagangan manusia di Zimbabwe. Kondisi tersebut menjadi faktor yang memperpanjang maraknya perdagangan manusia. Studi ini merekomendasikan kepada pemerintah agar menyelesaikan persoalan perdagangan manusia dari tataran akar rumput disertai kooperasi regional dan inisiatif internasional.
\end{abstract}

Kata kunci: perdagangan manusia; perempuan; Republik Kedua Zimbabwe; eko-sosial; teori konflik 


\section{Introduction}

In Zimbabwe, human trafficking is among the top societal concerns in the turn of the second republic under the leadership of the Honorable President Emerson Mnangagwa. Human trafficking, in its various forms, constitutes a severe challenge to humanity affecting men, women, girls, and boys, respectively. Masika (2002), Chamie (2015), Gow et al. (2015), Kurima (2017), Dubrawski (2015), $\&$ Peksen et al. (2017) concur that women and girls make up the highest percentage of those who trafficked for sexual exploitation. Osezua (2016) \& Omilusi (2019) state that human trafficking denotes the transferring and abusing of human beings for forced labor or commercial sexual exploitation and other forms of exploitation. In the same light, Seo-Young (2015), defines human trafficking as the recruitment, transportation, transfer, harboring or receipt of persons through a threat, use of force or other forms of coercion, abduction, fraud, deception, the abuse of power or a position of vulnerability for exploitation. For Seo-Young (2015), exploitation entails forced labor, sexual exploitation, and the removal of bodily organs. Contextually, many victims of trafficking in Zimbabwe are mainly trafficked forsexual and/or labor exploitation. The victims of human trafficking may suffer severe physical, sexual, psychological, and emotional health consequences as they are often subjected to a range of abuses such as physical violence, sexual assault, emotional abuse, mind-control, and torture (Chamie 2015).

According to Turner (2015) \& Molland (2019), human trafficking is not a new social phenomenon and it can take place both internally and externally. Trafficking in human beings has been equated to modern-day slavery (Weiss 2015, Chibwe 2016). It is a crime committed against the hopelessness of the society's people in question, hence the formation of a human rights violation (Davy 2015, Jones \& Lutze 2016). More recent interest concerning human trafficking has been persuasive and gained momentum among various scholars and policy-makers at both the national and global levels (Pourmokhtari 2015, Molland 2010). It has received sweeping condemnation in offline and online media; however, the problem persists, particularly in Zimbabwe.

Human trafficking is recognized internationally as a violation of girl's and women's human rights and as a form of gender-based violence as stated in numerous regional and international human rights instruments such as Article 3 (a) of the United Nations Protocol to Prevent, Suppress and Punish Trafficking in Persons especially Women and Children, the African Charter on People and Human Rights, in the protocols on the Human Rights of Women (the Maputo Protocol), the Africa Charter on the Rights and Welfare of Children, the convention on the elimination of all forms of violence against women and girls (CEDAW), the United Nations (UN) under the Human Rights Convention and the Convention on Violence Against Women (VAW) of 1993. Advocating for a society where gender equality prevails is a call made by UN Women, United Nations Population Fund (UNFPA) Zimbabwe, SDGs especially goal number 5, World Health Organization (WHO), United Nations Children's Fund (UNICEF) Zimbabwe, Southern Africa Development Community (SADC), the Zimbabwe Constitution, the Zimbabwe Domestic Violence Act of 2006 (DVA), the Musasa Project, the Women Lawyers Association of Zimbabwe (ZWLA), the Women's Action Group (WAG), the Zimbabwe Women Resource Centre and Network (ZWRCN), the Women Aids Support Network (WASN) and the Musasa project with other relevant organizations in Zimbabwe. However, human trafficking is still a cancerous social phenomenon that has eroded Zimbabwean society in particular and the world.

The study gives a brief overview of the inescapable involvement of human trafficking, socio-economic, and political space. The reasons behind human trafficking in Zimbabwe vary in terms of time and space. In this regard, the researcher finds it useful to contextualize the study into a specific period and place, specifically the second republic of Zimbabwe and Seke district. The phrase 'second republic' or 'second dispensation' is used synonymously in Zimbabwe to refer to the period after the fall of President Robert Mugabe's long-serving. In November 2017, President Robert Mugabe's 37-year reign came to an abrupt end in a coup d'état that shocked the world. On $18^{\text {th }}$ November 2017, the selfexiled Mnangagwa implored Zimbabwe's cornered President, Robert Mugabe, to heed the people's voice and resign, invoking the mantra 'the voice of the people is the voice of God' (Chimininge 2019). The slogan gained currency among the politically and economically-troubled Zimbabweans. It catapulted Mnangagwa's popularity to hero status as a politician who would transform and revive the dead political, social, and economic institutions. 
When President Mnangagwa took over from President Mugabe on $24^{\text {th }}$ November 2017, the economy was already in a perilous state, and politics became polarized. The nation had high expectations that the new leader of the new dispensation or second republic would take the nation back to its days of glory when it used to be the breadbasket of the Southern African Development Community region (SADC); however, at a time when the majority of Zimbabweans were hoping for a new change in the political and economic realm, Mnangagwa's propaganda has come back to haunt his leadership as the country continued to be rocked by the political and economic ills.

The condition of ordinary citizens has worsened, prompting Zimbabweans to resort to continuous demonstrations. These demonstrations were motivated by several ills, including corruption, power (electricity) and fuel shortages, cash shortages, a lack of political reforms as security forces such as Zimbabwe Republic Police (ZRP) and Zimbabwe Defense forces (ZDF). It deployed on the street to brutalize citizens for demonstrating against the government, shortages of essential goods, unemployment as there are no jobs at the market due to the closure of many companies and industries prompting excessive retrenchment, a vendor-police clash in the name of Murambatsvina (operation clean-up or restore order). Lack of sufficient water supply, politically-motivated violence against citizens in the case of demonstrations from grieving citizens, namely teacher-doctor civil servants and the politicization and abuse of food aid, are all prevalent in the country (Burke 2019). President Mnangagwa's policies have caused excruciating pain, particularly for the general populace, thereby impoverishing many Zimbabweans. For these reasons, among the other multifaceted socio-cultural factors such as family disintegration, gender inequality, and the feminization of poverty, the feminization of global migration and the patriarchy that is fuelling human trafficking in Zimbabwe. To this end, the socio-cultural and eco-political context of Zimbabwe's second republic exacerbates human trafficking.

The continuous human trafficking makes it crystal clear that Zimbabwe is one of the many countries in southern Africa that fails to combat the aforementioned inhuman acts. There is a proliferation of academic research and governmental reports on human trafficking in Zimbabwe; however, this study's argument develops centered on the notion that the government of the second republic and its holistic institutions have been agents in the continuation of human trafficking in the country. Thus, the study seeks to fill the gap of dearth contemporary literature with particular reference to Seke district. Human trafficking victims from Zimbabwe are taken around the globe. Zimbabwe became a route, source (hotspot), and the market for human trafficking. For instance, trafficking victims are taken to Asia, Europe, and Saudi Arabia and also within Africa itself (Dodo \& Dodo 2012). Due to the broadness of the topic, in this study, the researcher focused mainly on Zimbabweans' human trafficking to the neighboring country of South Africa. This study targeted women victims of human trafficking as they are mainly trafficked for the purpose, such as labor exploitation and domestic sex slaves in South Africa.

Given Zimbabwe's political and economic environment, there is a lack of or negligence on law enforcement regarding human trafficking. In such circumstances, eradicating human trafficking in Zimbabwe becomes a daunting mission. Thus, the article explores the phenomenon of human trafficking within the current eco-political and socio-cultural environment of Zimbabwe's second republic. As such, this study's originality lies in its fieldwork contributions to the already available human trafficking scholarship by discussing the eco-political and socio-cultural context in the second republic. This study has employed the data obtained from informants from August 2018 to November 2019.

This study employs the conflict theory that has emerged in the late $19^{\text {th }}$ century from Karl Marx and Friedrich Engels (Hopper 2016). Conflict theory explores power structure and power disparities, which refer to how power differentials affect social inequality (Rossel 2013). Conflict theory serves as the polar opposite of functional theory. Conflict theory operates on the premise that humans are self-centered and competitive by being forced into conflict over scarce resources and wealth (Rossel 2013). Within conflict theory, the wealthy classes can maintain power over the lower-income class by allowing the oppressed groups to believe that the advancement of another oppressed group will be to 
their detriment; therefore the oppressed groups assist in the oppression of each other in the hope that they will be the one to advance (Rossel 2013). From this perspective, social order exists through the coercion of oppressed and less powerful groups by the ruling and more powerful classes. Therefore, human trafficking in Zimbabwe can be well understood through the use of conflict theory. It stems more from the inequalities faced by the majority of Zimbabweans. In relation to human trafficking, conflict theory aims to offer a comprehensive explanation as to why and how social inequality, power imbalances, and oppression can occur. Within the Zimbabwean context, the eco-socio and political inequalities have accelerated the number of human trafficking cases. Human trafficking is a form of labor trafficking that fulfills the need for more labor to increase profit. Sex trafficking fulfills the need to provide money to pimps. To bring to light the plight of trafficking victims whose most basic human rights have been violated, the study argues that inequalities and the power relations from within the eco-socio and political structure in Zimbabwe has led to the exacerbation of this social phenomena. Thus, this study will view human trafficking as a form of gender discrimination and a human rights violation where the power embedded in the hands of those who are exploiting women and taking advantage of the country's eco-political situation. Through this theory, this study can explore the interplay of the complex themes present in the human trafficking discourse through a gender lens, giving the researcher a platform to challenge the present eco-socio and political environment. Therefore, this theory is relevant and applicable to the Zimbabwean context and, in particular, to the human trafficking social phenomena. This article seeks to document the eco-socio and political practices that have made the district more vulnerable to human trafficking. The researcher will thus be able to explain how and why human trafficking occurs.

\section{Research Method}

This study was conducted in the district of Seke in Zimbabwe. Qualitative research methods employed in this study. According to Kumar (2011) and Bhattacherjee (2012), the qualitative method is a systematic and subjective way of describing life experiences and situations to give them meaning. Walliman (2010) stated that qualitative research is a naturalist approach that focuses on understanding the meaning that people give to the phenomenon within their social setting. For this reason, the qualitative method is of great significance in this study because it is a suitable method to use to explore and understand the eco-socio and political context of the phenomenon of trafficking women and girls in Seke District, Zimbabwe. The primary data gathered from five female core informants who were the direct victims of human trafficking and three of their significant others who were the parents and guardians of the victims of human trafficking. The snowball sampling technique was employed to obtain the female core informants for the in-depth interviews. Due to the topic's broadness, the study has not had an opportunity to get the victimizers' voice. The researcher made use of the secondary data available from relevant textbooks, journal articles, internet, NGOs, and government records to gain complete detail and an in-depth record of the phenomenon of human trafficking. The researcher made the transcript by first translating the primary data from the Shona language into English. The categorization and classification of the raw data were done and linked to the themes, secondary data, and social phenomena under investigation for easy data analysis. Lastly, the researcher presented the data in a narrative form.

\section{Results and Discussion}

Human trafficking in Zimbabwe is not a new phenomenon, one point that can hardly be denied is that it has gone out of hand. The continuation of the Zimbabwean crisis at the turn of the second republic has promoted fertile grounds for the unprecedented increase in the trafficking of women and girls. It is one of the most significant challenges that Zimbabwe is facing as the source, transit, and destination for men, women, and children exposed to polymorphous forms of trafficking such as forced or cheap labor in commercial and household places and sex trafficking among others. However, the results-focused mainly on women and girls as the victims of human trafficking.

Narrating her ordeal, a core informant, MN, a 17-year-old girl from Seke District who was a victim of human trafficking to South Africa. 
"My relative in South Africa knew that my family was struggling to pay up her ordinary level exam fees and offered her a job in South Africa. I was trafficked to South Africa using the Gonyeti (Cargo Carrying truck), who had connections with the relative and new employer in SA."

According to MN, she was smuggled to the South African side by the cargo truck drivers because she had no proper legal documents, and she explained:

\begin{abstract}
"Upon arrival in SA, my relative called the family who was supposed to work for, and when I eventually arrived at the family's home, I became a victim of forced labor and demeaned verbally. I worked for hours and months without salary. Because I had no legal documents and threatened to kill me, if I report the issue to the police, they will put me in jail for breaking the immigration laws."
\end{abstract}

From the explanation given by the core informant, it can be attested that many of the women who become the victims of trafficking are people who do not possess any legal documents. Many vulnerable women and girls from Zimbabwe are trafficked into South Africa with the assistance of taxi or commuter drivers known as Maraicha or Malaicha or Omalayitsha. They transport them to the border at Beitbridge or close to other unofficial crossing locations. The drivers are people who are well-connected to traffickers on both sides of the border. Vulnerable women and children are later subjugated to forced labor and sex trafficking.

Both women and girls have been smuggled into South Africa through the Beitbridge border post. From a critical point of view, Zimbabwe has become a hub for human trafficking due to its laxity concerning the laws based on this social phenomenon. The laxity of the government, especially the rule of law, continuous human rights violations, and ineffective economic policies has led to innocent citizens being exploited in neighboring countries such as South Africa. In recent decades, Zimbabwe has been a troubled nation due to the further decline in law enforcement, especially on ordinary people. Such a decline in the rule of law has paved the way for the widening gap in the scaling-up of efforts to bring an end to human trafficking policies (Dodo \& Dodo 2012, Capron \& Delmonico 2015). The responsible authorities who are supposed to combat human trafficking are being corrupted by those who are involved in trafficking other beings. Therefore, poor law enforcement is the primary driver of the increased human trafficking problems in Zimbabwe. The loopholes in the rule of law in Zimbabwe have also provided fertile grounds for human traffickers to commit crime because there is little or no penalty to stop them. Zimbabwe's eco-political and socio-cultural hardships have made those in power accept bribes for the de-humanizing, dissocializing, and desexualizing of other human beings. The continuous human rights violations in Zimbabwe in the form of trafficking are a crystal clear sign of a troubled nation that has been hit by a plethora of crises.

In wanting to flee from Zimbabwe's economic and political hardships, T, a 33-year old mother of four, accepted a job offer in SA. She alluded that:

“... when they arrived in SA, she was forced into sex trafficking for quick money in order for her to pay back the debts. T was identified as a victim of sex trafficking in a police raid on the brothel."

From the narration, it is crystal clear that the victims of trafficking kept against their will. Trafficked persons, in most cases, find themselves in desperate circumstances where they cannot report the crimes committed against them because of their illegal status (Davy 2015, Netsianda 2019, Chamie 2015). Due to their unlawful entry into the country, the victims find it difficult to seek help from the police. Therefore, the economic and political hardships prevalent in Zimbabwe, particularly in the district of Seke, have exacerbated the trafficking of women and girls. MY, an 18-year-old woman explained:

\footnotetext{
"A trafficker posing as a relative trafficked me. I was offered a lucrative job contingent on her moving to SA. With the hope of a better life and opportunities outside Zimbabwe, I agreed. Once in SA, however, I learned that the job was no longer available. I became financially dependent on the trafficker, and I could not repay. After some time, the trafficker coerced me into sex trafficking through the use of debts bondage."
} 
One of the significant others, MG aged 73 (MY's Grandmother) lamented that:

"Ndinozvidemba iniwo nditori chirikadzi yakwegura handina chandiinacho cheuviri, zvimwe ndingadai ndakamuti rega kuenda Joni (SA), ndaiti awana basa rinosimudzira urombohwatiinahwo uhwu."

It translates as:

"I blame myself for allowing my granddaughter trafficked by our own relative who promised she will be working in a restaurant. I thought my grandchild was given an opportunity to improve our living standards."

Human trafficking has led to the disintegration and erosion of family ties and the re-production of slavery. The hostile environment further worsens this for women involving domestic violence and political violence (Zengenene \& Susanti 2019). Family members are a catalyst for participating in the inhuman act of recruiting their disadvantaged family members into human trafficking. Human trafficking victims are lured in with the promise of good jobs and a good living standard. The unrealistic promises made in South Africa of it being a land of easy employment has made many women vulnerable to traffickers. Therefore, in the search for better living conditions in neighboring countries, women have become victims of de-socializing, de-humanizing, and desexualizing trafficking acts. Traffickers continue to take advantage of the eco-political mayhem that has rocked the nation for decades.

After being asked about who had received her and the traffickers' intention, C, a 22-year old, disclosed the following:

"I was sold to South African Brothels to work as a stripper (strip dancer). It happened after the job opportunity in the home as a helper did not materialize. After dancing, we would be taken to private rooms and sleep with different men. At first, I used to cry because they were forcing themselves on me (rape). I was powerless as I had no legal documents. If I went to the police, they would deport me to Zimbabwe. I went to South Africa through border jumping."

Some of the border jumping women and girls often targeted by the traffickers and further transferred to criminal gangs that subject them to abuse, including forced prostitution in the Musina, Pretoria, Durban, and Johannesburg provinces South Africa. At this juncture, the study argues that the continuous vulnerability of women to trafficking reflects a lack of awareness in Zimbabwean society. In response to the question of who trafficked her, TF, a 27-year-old woman, recounts that:

"I was a vendor selling vegetables and tomatoes in Harare's street, so I heard from my cousin who is working in South Africa, but I did not know the nature of the job. She told me she has some friends who helped young women and girls get some jobs in South African restaurants and homes. Because the police and the city council always harass us, our staff are always taken during the riots. I thought it was a good opportunity to escape from this misery as Zimbabwe's situation is unbearable. I had no idea that I was going to be a victim of trafficking. She had promised to take care of me. When we arrived in SA, my cousin sister and her partners forced me to engage in commercial sex. At first, I would refuse and get beaten until I finally complied. It was during the Police raids when I was rescued."

In addition, BT aged 58 and AT aged 53, the parents of Tafara, narrated:

"Takatadzira mwana vedu, hatina kumupa the protection yaaifanirwa kuvana semwanasikana. Takamupa pressure yekuti aite zviri kuita vana vevamwe. Ndizvo zvakapedzisira zvaita kuti awire munjodzi atorwa na sisi vake mwana vababamukuru kuenda kunoshanda Joni. Hapana chatakagona, mwana vedu awa neutachiona aibatwa chibaro, nevarume vasina kuzvidziwirira utachiona." 
It means:

"We have failed our daughter, and we never protected her like we should have done. We were so adamant for her to be like what other daughters are doing working in South Africa (Joni) without having the proper knowledge that our daughters sold into sex slavery. Now our daughter is infected with HIV, they raped and sexually abused her."

Upon critically analyzing the above explanations by both the core informants and significant others, it can be argued that the smuggling of people to South Africa has turned into human trafficking. Smuggling can be through voluntary means to obtain work while some are smuggled against their will for labor exploitation and commercial sex (Weiss 2015). Those who have been smuggled through border jumping later held in places such as restaurants, brothels, farms, and homes, among other places. These people tend to be subjected to sexual exploitation and forced labor. Therefore, it is the combination of push factors from the place of origin and pulls factors from the receiving nation (South Africa). Effectively addressing human trafficking is a priority of the government, national agencies, and other international initiatives to curb and eliminate all forms of trafficking. However, the drivers and the root causes of the problem deeply embedded in the Zimbabwean government's eco-political and social fabric. The hostile environment in the turn of the second republic has not paid attention to the majority of poor citizens' dire needs. Attention has not been paid to the highly skewed socio-economic and political havoc. From a conflict theory point of view, such a hostile structure and environment have made women and girls together with hopelessness children vulnerable to human trafficking. Traffickers in this context have been elevated as economic liberators. It makes curbing human trafficking in Zimbabwe a complicated issue. Thus, combating human trafficking remains a daunting challenge in Zimbabwe.

Drawing from a critical theory perspective, the government offices' centrality in Harare and Bulawayo has made the government restrict the issuing out of travel documents such as passports (Dzirutwe 2019). The poor who are heavily affected by the socio-cultural and eco-political hostile environment and are desperate to flee from the country, have resorted to accepting jobs in SA even if they are not skilled enough and without proper documentation. Zimbabwean women who arrive in South Africa without papers or passports destined for sexual exploitation. The Zimbabwean socio-political and economic environment's depressing reality has put women at a high risk of being trafficked. Therefore, within a conflict perspective, Zimbabwe's socio-cultural and eco-political situation has exposed women and girls to trafficking. The current eco-political environment of Zimbabwe has led to the continued growth of social fabric erosion. As such, Seke district became a fertile ground for human traffickers as they target the marginalized. Thus, it has become a target. The growing inequalities, unequal distribution of resources and power in the umbrella sense of eco-politics in Zimbabwe involve many push factors that exacerbate the rise in human trafficking.

Zimbabwe's economic woes exacerbate the existing inequality between those who are politically connected (a few elite politicians) and those who are not. Political and economic governance issues have worsened the impact of the cycle of poverty (Dodo \& Dodo 2012, Weiss 2015). The continued harassment by the state actors such as the Zimbabwe Republic Police and Zimbabwe Defence Forces has increased the vulnerability of the people. In addition, the second republic, the depletion of social services and living standards, has been on the increase, and this further worsens the subjugation of the disadvantaged people in the community who are at risk of being lured by deception. The police and soldiers are brutalizing and killing people in the streets. Additionally, most public sectors have gone on strike over unpaid salaries. President Mnangagwa has failed to keep the promises that he made during the 2018 general elections campaign to revive the economy and social and political institutions. It can be argued; there is a contradiction between what the president says and what is happening on the ground. The president became popular with the saying Zimbabwe is open for businesses, yet society itself is not open for the locals. The second republic of Zimbabwe, or the second dispensation, has witnessed a turnaround of the economic and political misfortune. It is in this context that human traffickers have taken advantage of the eco-political situation. 
Like the first republic, the second republic under President Mnangagwa has continued the culture of having the political elites' interests come first before those of the citizens. Zimbabwe's government has been reluctant to provide sound policies to revive the home situation to avoid the push factors tied to human trafficking. It is crystal clear that little/nothing has changed in Zimbabwe since the end of the first republic as the economic and political policies are still not serving ordinary people's needs. Thus, from a critical theory perspective, human trafficking has become a more cancerous social phenomenon affecting society and the nation. The factors, as mentioned earlier, have implications for human trafficking in Zimbabwe. The disadvantaged groups of people in society, particularly women and girls, have become the victims of trafficking due to the hostile environment posed by the ecopolitical and socio-cultural environment.

It is based on this premise that human trafficking is rooted in Zimbabwean society's socio-economic and political structures. Therefore, the power to abandon the practice resides within the government of Zimbabwe. Providing the eco-socio and political reforms necessary to revive people's living standards can help combat human trafficking. The focus should be on eradicating the push factors that have lured many desperate women and girls in becoming the victims of trafficking in the neighboring country of South Africa. Only government-driven eco-socio and political reforms will put an end to the human trafficking practice. The government should create an environment conducive to all sexes leading decent lives, thereby combating any desire to leave their place of origin under the pretext of getting employment and accessing better living conditions.

On this note, this study, therefore, recommends that in order for Zimbabwe to have a society that is free human trafficking, there is a need for the present government to solve the root cause of Zimbabwe being a hotspot and target for traffickers. With enforcement in this manner at the grassroots level, together with the regional and international initiatives, human trafficking will be combated. The government should further scale-up its efforts to identify and protect trafficking victims. Responsible government departments such as Zimbabwe Republic Police's Victim Friendly Unit (VFU) should further foster the protection of the women and girls who are most affected by the social phenomena of human trafficking. A hospitable environment should be fostered for NGOs to work with the government to provide services and raise awareness of human trafficking and assistance for victims.

\section{Conclusion}

Based on this study, the discourse of human trafficking in Zimbabwe is a complex phenomenon. Upon the advent of President Mnangagwa's second republic, the ongoing socio-economic problems combined with the political problems have made it more complicated than before. It has mostly exacerbated women's and girls' vulnerability to external human trafficking as they would need to escape from the hostile environment.

\section{References}

Bhattacherjee A (2012) Social science research: Principles, methods, and practices. Textbooks Collection 3, University of South Florida.

Burke J (2019) Zimbabwe crackdown could last month activist fear, The Guardian, 27 January. [Accessed 14 August 2019]. https://www.theguardian.com/world/2019/jan/27/zimbabwecrackdown-will-continue-for-forseeable-future-activists-fear.

Capron AM \& Delmonico FL (2015) Preventing trafficking in organs for transplantation: An important facet of the fight against human trafficking. Journal of Human Trafficking 1 (1):5664. https://doi.org/10.1080/23322705.2015.1011491.

Chamie J (2015) Human Trafficking: A Serious Challenge to Humanity. In: Karen MR (ed). Great Decisions. New York: Foreign Policy Association.

Chibwe L (2016) An appraisal of legislation and policy on human trafficking in Zimbabwe. Dissertation, Midlands State University, Zimbabwe. 
Chimininge V (2019) 'The voice of the people is the voice of god.' a critical reflection on the use of god in promoting political legitimacy in the new dispensation in Zimbabwe. Journal of Politics and Religion 32 (2):37-59.

Davy D (2015) Understanding the support needs of human-trafficking victims: A review of three human-trafficking program evaluations. Journal of Human Trafficking 1 (4):318-337. https:// doi.org/10.1080/23322705.2015.1090865.

Dodo O \& Dodo G (2012) Human trafficking in Zimbabwe: An impediment to national development. International Journal of Humanities and Social Science 2 (7):146-150.

Dubrawski A, Miller K, Barnes M, Boecking B, \& Kennedy E (2015) Leveraging publicly available data to discern patterns of human-trafficking activity. Journal of Human Trafficking 1 (1):6585. https://doi.org/10.1080/23322705.2015.1015342.

Dzirutwe M (2019) Zimbabwe runs out of passports, adding to long list of shortages, Reuters, 3 July. [Accessed 20 August 2020]. https://www.reuters.com/article/us-zimbabwe-economy/ zimbabwe-runs-out-of-passports-adding-to-long-list-of-shortages-idUSKCN1TY1DG.

Gow AG, Barlott T, Quinn K, Linder J, Soler A, Edwards G, \& Hossain S (2015) Project backpage: Using text messaging to initiate outreach support for victims of human trafficking and sexual exploitation. Journal of Human Trafficking 1 (4):259-274. https://doi.org/10.1080/2332270 5.2015.1016769.

Hopper EK (2016) Trauma-Informed psychological assessment of human trafficking survivors. Women and Therapy 40 (1-2):12-30. https://doi.org/10.1080/02703149.2016.1205905.

Jones TR \& Lutze FE (2016) Anti-Human trafficking interagency collaboration in the State of Michigan: An exploratory study. Journal of Human Trafficking 2 (2):156-174. https://doi.or $\mathrm{g} / 10.1080 / 23322705.2015 .1075342$.

Kumar R (2011) Research Methodology a Step-by-step Guide for Beginners. London: Sage.

Kurima P (2017) The pattern of human trafficking: Comparative case studies of Zimbabwe and the Greater Mekong Sub-region. In: Salaya Conference on Irregular Migrants, Refugees or Victims of Human-Trafficking? Analysis, Advocacy and Assistance between Categorizations and (Self) Identifications, 17 Juni, Bangkok.

Masika R (2002) Gender, Trafficking, and Slavery. Oxford: Oxfam Focus on Gender.

Molland S (2010) "The perfect business": Human trafficking and Lao-Thai cross-border migration. Development and Change 41 (5). https://doi.org/10.1111/j.1467-7660.2010.01665.x.

Molland S (2019) What happened to sex trafficking? The new moral panic of men, boys and fish in the Mekong Region. Journal of Social Issues in Southeast Asia 34 (2):397-424.

Netsianda M (2019) SA police raid notorious brothels: Zimbabwean sex slaves freed, Chronicle, 28 October. [Accessed 1 December 2019]. https://www.chronicle.co.zw/sa-police-raidnotorious-brothels-zimbabwean-sex-slaves-freed/.

Omilusi M (2019) A researcher's visit to Italy: Human trafficking and the Nigerian-Sicilian mafias. African Sociological Review / Revue Africaine de Sociologie 23 (1):110-122.

Osezua CO (2016) Gender issues in human trafficking in Edo State, Nigeria. African Sociological Review / Revue Africaine de Sociologie 20 (1):36-66.

Peksen D, Blanton SL, \& Blanton RG (2017) Neoliberal policies and human trafficking for labor: Free markets, unfree workers? Political Research Quarterly 70 (3):673-686. https://doi. org/10.1177/1065912917710339.

Pourmokhtari N (2015) Global human trafficking unmasked: A feminist rights-based approach. Journal of Human Trafficking 1 (2):156-166. https://doi.org/10.1080/23322705.2014.1000078.

Rossel J (2013) Conflict theory. Oxford Bibliographies. https://doi.org/10.1093/OBO/97801997 56384-0035.

Seo-Young C (2015) Evaluating policies against human trafficking worldwide: An overview and review of the 3P index. Journal of Human Trafficking 1 (1):86-99. https://doi.org/10.1080/2 3322705.2015 .1014660 . 
Turner I (2015) Human rights, positive obligations, and measures to prevent human trafficking in the United Kingdom. Journal of Human Trafficking 1 (4):296-317. https://doi.org/10.1080/233 22705.2015.1034612.

Walliman N (2010) Research Methods: The Basics. London: Routledge.

Weiss MS (2015) Human trafficking and forced labor: A Primer. American Bar Association Journal of Labor \& Employment Law 31 (1):1-52.

Zengenene M \& Susanti E (2019) Violence against women and girls in Harare Zimbabwe. Journal of international Women's studies 20 (9):83-93. 